\title{
FAMILY HISTORY AND SOCIAL NETWORK
}

\section{AMONG NYUNGAR PEOPLE}

\author{
Christina L. Birdsall
}

This study concerns an Aboriginal group from Perth and the towns of Western Australia who call themselves Nyungars. Nyungar was originally the word meaning 'man' or 'person' in the dialects of the Aboriginal language once spoken in the south-west of Western Australia. 1 Nowadays, the first language of Nyungar people is English.

In pre-colonial times, the Nyungar people's lands were limited to the south-west corner of the State as shown on the map. ${ }^{2}$ With the onset of colonisation, however, many Nyungar were forced from their lands.

The Swan River Colony was established in 1829 when it is estimated that there were around 6000 Nyungar people living in that region of the colony. ${ }^{3}$ By 1901 , three years after the Western Australian Colonial Government had assumed control of Aboriginal affairs, this number had dropped to an estimated 1500.4 Despite this devastating reduction of the Nyungar population, and the accompanying dispossession of their lands, the government had not enacted any policy which effectively broke the association of the Nyungar peoples with their lands.

This situation changed with the passing of the 1905 Aborigines Act. This act, ostensibly protectionist in its objectives, gave the government power to rule the everyday lives as well as the futures of individual Aboriginal people virtually as it saw fit. It also gave the government control over persons of mixed descent who, previously, had been largely free of the control of special Aborigines legislation. The Government was now able to remove the children of mixed descent from their parents and place them in special missions and settlements, to be brought up wholly within these institutions, away from the influence of their Aboriginal families. 5 The policy of segregation of Aboriginal people from the wider community and Aboriginal children from their parents was rigorously pursued. By the mid1920s, nearly 15 per cent of the Nyungar population was interned at Moore River Native Settlement $100 \mathrm{~km}$ north of Perth and south of Moora. The number held at the settlement continued to grow over the next decade. ${ }^{6}$

Christina Birdsall has a $B A$ degree from the University of Florida, Gainesville, and an $M A$ degree from the University of Western Australia, to which she has recently submitted a PhD thesis on Aborigines in the settled areas of Western Australia.

1 Douglas 1975:5.

2 Map 1 is reproduced with permission of R.M. Berndt and the University of Western Australia Press. His map is a modification of the one drawn by Tindale (1940). Daisy Bates (1985) also includes a map of the area drawn by her secretary between 1936 and 1940 .

3 Berndt 1979.

4 Western Australian Census 1901, quoted in the Handbook of Western Australia, 1905, vol. 5.

5 For discussions and analyses of this period see Biskup 1973, Haebich 1982, 1985 and Howard 1980, 1981.

6 Howard 1980:302. 
This policy of segregation, forced migration and internment over a period of nearly fifty years, effectively broke the association of people with land for a large proportion of the Nyungar people. It was an era of institutionalisation, pauperisation and disenfranchisement which continued until 1951 when the Federal Government formally adopted assimilation as its Aboriginal policy. At a meeting of State and Federal ministers responsible for Aboriginal affairs, held in that year, a statement of principles of assimilation was formulated to which all authorities subscribed. ${ }^{7}$ The settlements were closed, and most of the special legislation affecting Aborigines was withdrawn.

With this development there began a dispersal of the Nyungar people. Although many remained in the south-west, others migrated north in search of work, and also, adventure. They worked on the stations throughout the north, but seem to have established centres of Nyungar population only in the towns along the coastal strip between Geraldton and Broome. My research was conducted among one of these coastal groups, an extended kin group of 161 individuals. Part of the purpose of this paper is to explain how they came to be located in the north. I call them the McNish family.

The Nyungars of the northern coastal strip and those of the south-western corner type one another as 'Northerners' and 'Sou'westers' respectively. The differences between them lie primarily in their relationships to the regions they occupy.

The original countries of the Nyungar are located in the south-west. For those Nyungar who still live in that region the particular areas of the south-west, identified with and occupied by the members of particular extended kin groups, are their own, spiritually, historically, and socially. A Sou'wester will speak of 'my country' and include in this both the towns and the countryside within the area so identified.

The Nyungar of the northern coastal strip are different. They do not speak of 'my country' but of 'my town'. They travel the long distances between the towns inhabited by their families and tell stories which concern only the road and not the country lying beyond. It is not until they reach the outskirts of the town that the stories conveying historical and spiritual association begin, and these stories nearly all concern their own groups of kin. It is as members of an extended kin group come to be buried in a town that spiritual association of the group with the town develops. But this develops only if people of that kin group continue to live there; growing up, raising their children, tending the graves of their dead and growing old. Through this process they come to identify themselves with the town. They may live elsewhere at various times, but that town is home and they will wish to be buried there.

The Nyungar people exhibit a number of structural variations in the organisation of their kin groups which are related systematically to a set of organisational principles, or norms. I will present examples of such variations with a view to demonstrating this relatedness.

I seek to show that in order to understand the regional and structural variations observable among Nyungar kin groups, they should be viewed within the contexts of (a) the history of extended family groups, and (b) the life experience of key individuals within those groups.

The word 'family' has a range of uses among Nyungars. It can refer to the children of the person speaking, or the large kin group from which the kin network is recruited and, rarely, it can refer to the kin network itself. More usually, the kin network is referred to as 'our lot', 
or 'mob' or 'that part of the family'. The words lot and mob themselves have a range of uses and are not restricted to the indication of kinship based groups. There is thus no Nyungar term which is used specifically to refer to the kinship based group I refer to as the kin network. Hence the necessity to provide a sociological term which characterises its most obvious features - a kin-based group which co-operates economically and socially, whose members associate intensively with one another and who are inter-connected in a variety of ways. In contrast, there is a Nyungar term for the large kin group from which the network is recruited. This group is always said to be 'all-one-family' and no other use is made of this phrase.

The all-one-family is a cognatic descent group. The basis on which the kin network is recruited from this larger group is what may be termed the 'rearing-up' relationship. 'Rearingup' is the Nyungar gloss for child rearing. A rearing-up relationship exists between the individual and those whom that individual was reared-up with and reared-up by; and also between the individual and those whom she is currently rearing-up.

The Nyungar system encourages extensive identification of matrilateral kin with lineal kin. Thus, the children of siblings, sisters in particular, are taught to regard their matricousins as siblings. Aunts are in many circumstances equated with the child's mother. Just as sisters tend to rear their children up co-operatively, their daughters may in adulthood rear their own children up co-operatively. If that happens, then these children will address their mothers' cousins as 'aunty' and will regard one another as siblings although they are in fact second cousins.

This results in a wide range of kinfolk who possess various types of rearing-up relationships with one another. If diligently pursued it can result in a very large number of closely associated kinfolk indeed. In the recruitment of the kin network, kin relationships are important but, in and of themselves, they are not enough. In order for these relationships to be effective they must be enacted. In the enactment of kin relationships the primary focus is on rearing-up, but continuous economic co-operation and an intensive pattern of association are also requirements. These effective kin relationships constitute social relationships and also pattern associated behaviour. Given this, it may well be asked what purpose does the all-one-family, the cognatic descent group, serve?

The all-one-family is an exogamic unit. The degree of relationship above which marriage or any sexual liaison is forbidden depends on the group's history. Usually, sexual liaison is forbidden between cousins of the third degree or less. However, in certain circumstances this may be extended to fourth cousins or more. As an example, I turn to the all-one-family of which my subject group is a part. This all-one-farmily is split into two networks. This split occurred during the young adulthood of the third ascending generation of the all-one-family. Previously to this time the descent group was a large kin network, itself part of another descent group. A split can occur when a kin network is large, not because of feuding or enmity, but because there exists within the network a natural division of kin dividing it into two distinct sections, each descended from an individual in the fourth ascending generation. Each of these sections will be fairly large in numbers and have four generations represented in those numbers. These factors make it possible for each section to co-operate economically within itself and to establish lines of authority independently of the other.

Within the constituent networks of the McNish all-one-family, the older people and their children well remember their formerly close relationship with members of the other network. They no longer co-operate economically or closely associated with those people, but they still identify those people as their sisters, brothers, aunts and uncles. They have rearing. 
up relationship with all of them. The descendants of people who have a rearing-up relationship are barred from forming any sexual liaisons up to the third generation of descent. These descendants are in fact fourth cousins (see Diagram 1).

During the time when this group operated as a single set of effective kin, the children were taught that whether they were siblings, first cousins or second cousins, they were 'all family', and so the degree of their genealogical relationship ought to make no difference in their behaviour toward and treatment of one another. They should all be just like brothers and sisters. These children referred to one another's parents as aunty and uncle, whether the person so addressed was their parents' sibling or in fact their parents' first cousin. The grandchildren of these sibling-cousins are fourth cousins. They are still regarded as kin, too close to marry, but not because of their genealogical relationship. Strictly speaking, it is the social relationship of their grandparents, who are sibling-cousins, which precludes them marrying.

There are other options that may be taken by individuals which will result in a quite different kind of split in the network. These options are open to individuals as a result of their history of relationships with one another. For example, it would not be unusual to find within the same generation of a kin network twenty years difference in the ages of the oldest and youngest member of that generation. Owing to a variety of circumstances, the older person may have played a major role in the rearing-up of the younger person. The younger then looks to the older primarily as a parent rather than a sibling or cousin. In adulthood he/ she visits that person daily or even lives with her, and rears his/her children up under the guidance and with the help of that older person. This older person will most usually be a woman and she may similarly have played an important role in the rearing of other individuals in addition to her own children. It can happen in adulthood that individuals may choose to affiliate themselves with the older person rather than with their own parents. This pattern of affiliation lays the groundwork for a future split in the network. Such a split, when diagrammed genealogically, will not result in the lineal pattern of the previous example but in a lateral pattern that is the result of affiliation rather than descent (see Diagram 2).

In order to explain the pattern of a lateral split in a kin network, personal histories and personal affiliations must be taken into account. Individuals are free to affiliate with either their matri-kin or their patri-kin, and with either their male or female relations. Despite this freedom, it is the case that people tend to affiliate with their female matri-kin in preference to all other kin.

The Nyungar people have a saying that kin tend to 'fall on the mother's side'. This is evidenced in a number of ways. People tend to know their matri-kin better than their patrikin. When a marriage is established, whether it be a de facto or legal marriage, the couple tend to live near and associate more with the woman's family. Responsibility for children rests with the mother and her kin. In the event of the mother's death or her failure to conform to the norms of motherhood, her mother, aunts and sisters will often become responsible for the child, rather than the father or any of his kin. In Nyungar households, it is always a woman who is in charge. ${ }^{8}$

Given these facts of social organisation, it has been tempting to describe the Nyungars as

8 It is worth noting here that according to Bates (1985) the Nyungar of the Perth area had matrilineal descent of their moieties and semi-moieties. It is quite possible that the present-day Nyungar practice of 'falling on the mother's side' is a survival of the pre-colonial kinship system. I am indebted to Isobel White for bringing this to my attention. 
a case of matriliny according to a jural model; but this has not been possible. Descent does not pattern behaviour among Nyungar people, and the tendency to 'fall on the mother's side' is a trend rather than an absolute proclivity. Some groups appear to be recruited almost exclusively on the basis of matrilineal descent from a known female ancestor, others from a male ancestor. The two constituent networks of the McNish family, for example, are descended from two brothers. In one, network membership is recruited exclusively out of the matri-kin, that is the descendants of the daughters but not the sons of the male ancestor. In the second, membership is recruited from the descendants of both the sons and the daughters of the male ancestor. However, it was predominantly the female descendants of those sons and daughters who remained within their own family network, the male descendants often choosing to follow their wives' preference for maintaining associations among their own families.

While it is usual for men to follow their wives, or 'go the woman's way', some men do persuade their wives to go against common practice and go the man's way, that is, to live near and associate predominantly with his family. But this seldom happens and its rare occurrence is evidence of the strength of the expressed tendency to fall on the mother's side. There are other expressions which, when they appear in conversation, take on the character of generally accepted truths or maxims. 'A man can look after himself', it is said, 'a woman can't'. And further, 'a woman goes with people who are not her own, they'll never look after her or give her a home. They don't have to'.

These are neither statements of rules, nor of principles of social organisation. Rather, they are comments on trends of action interpreted according to a matri-centred ideology. The notion that it is proper to fall on the mother's side is a vaguely formulated expression of the same ideology. There are a number of ways in which people may conform to this ideology in their everyday lives, some optional and completely open to choice, others less so. The vagueness of the formulation of ideas expressing matri-centredness is not an indication of the weakness of the injunctions to fall on the mother's side. It is an indication that the Nyungar system is one which is open to a high degree of manipulation by the people who live according to it. This is attested to by the considerable variation of behavioural patterns with regard to pattern of association after marriage, recruitment of network membership, the reckoning of descent, and patterns of affiliation.

The particular pattern exhibited by a kin network is the result of its history and its present circumstances. For example, the sons of one particular kin network are encouraged to bring their wives into the family, that is, to go the man's way rather than the woman's. The women who accede to their husbands' wishes in this regard run the risk of being sanctioned within their own families owing to the grave insult they offer through such behaviour. However, the members of the men's families conform to common practice in other ways. Their households are run by women, they know their matri-kin better than their patri-kin, ultimate responsibility for children rests with the women, and so on. However, it will be the father's mother, aunts and sisters rather than the mother's corresponding kin who share this responsibility for the children with their mother.

A census of this kin network shows that in the generation now coming into adulthood, there is an abundance of boys but relatively few girls. Unless this family can circumvent this demographic chance by going the man's way rather than the woman's, their numbers will be sharply reduced owing to loss of membership through death and recruitment of their sons to other families through marriage. The parents of boys coming into adulthood must retain 
their sons and their sons' children if the kin group is to continue as a viable kin network. The women who marry into such a network must alter their own ideologies of marriage and affiliation, re-evaluating the relative importance of paternity versus maternity, and the marriage tie versus the ties of matri-filiation.

In another case, an elderly woman appeared to be without ties to any kin group larger than that comprising her own children and her grandchildren. This woman was one of those who was taken away from her family as a child, in the years when it was the practice of the Aborigines Department to put Aboriginal children into care at the discretion of the Department's agents. Now elderly, she knows who her relations once were. But as her knowledge is only a child's knowledge she cannot place most of them on a genealogy.

Some families lost many children this way. Dispersed, they have little chance of being reunited with their kinfolk. Some will have married into other groups, and successfully become members of various kin networks. Their responsiblities lie within those groups, not their natal groups. Others, as in the example quoted above will have failed, for various reasons, to become part of any kin group, and instead seem to be in the process of founding new networks which have only tenuous associations with other cognatic descent groups. Perhaps such a kin group will eventually become the basis of a new all-one-family. But at present, such a group will necessarily be small in numbers and without the interconnecting ties with kin in other towns which typify Nyungar kin networks.

Another group was also somewhat small in numbers, but for different reasons. ${ }^{9}$ Like the above example, this network lacked membership in a cognatic descent group. But unlike the above example, this network was entirely lacking in elderly people. On questioning, further peculiarities appeared. The members of this group had only tenuous kin links with one another. They were able to give only sketchy genealogical information about themselves and their claimed relations. Nevertheless they attempted to operate as though they were a kinbased Nyungar network. These people, as in the example of the elderly woman, were mission or settlement children. Now grown, they are without known or effective kin ties within the Nyungar world. The rules of social obligation which promote economic co-operation and the operation of a network of association and communication can operate only among people who have effective kin links with one another. People who have no relations are at a great disadvantage.

With regard to the size of a kin network, there is some evidence to suggest that this may be related to general economic circumstances. One kin network seemed at first to be small in numbers, in comparison to other Nyungar kin networks. However, four generations were represented and the age-sex ratio appeared to be unexceptional. The genealogy of this group showed that their membership seemed to have been recruited more selectively than is normally the case. Ordinarily, recruitment of a kin network will, in the second descending generation, include all the daughters and some of the sons of the founding parents, as in Diagram 1. However, this kin network, when diagrammed genealogically, revealed a lateral pattern of affiliation, as in Diagram 2. As pointed out earlier, in order for such elective filiation to take place among lateral kin, particular kinds of rearing-up relationships must exist among them. But there seemed to be other reasons which maintained selectivity of membership in this

9 This group was contacted by my colleague, Patricia Baines. I am grateful to her for sharing her experience with me. 


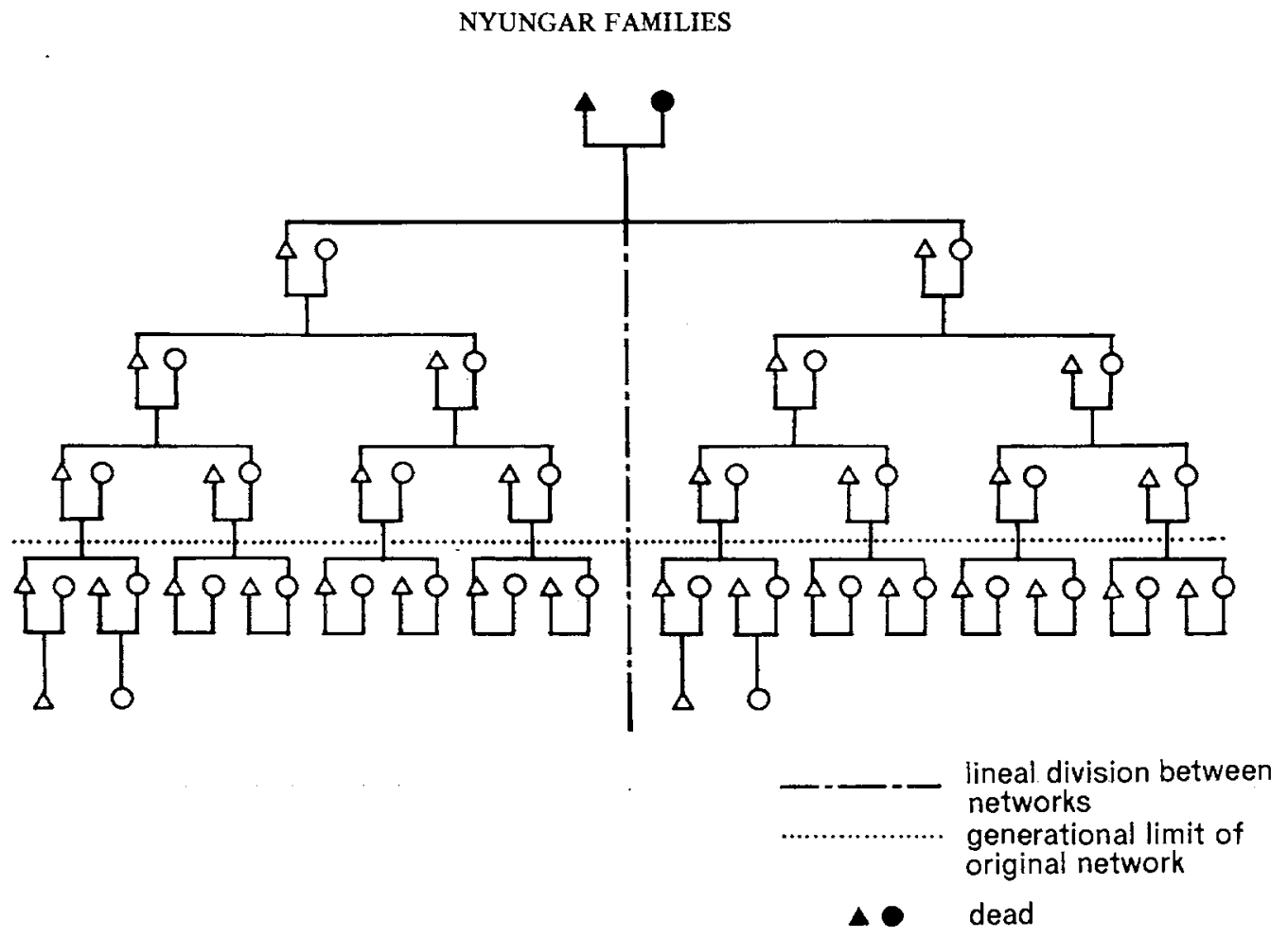

Diagram 1 : Lineal filiation
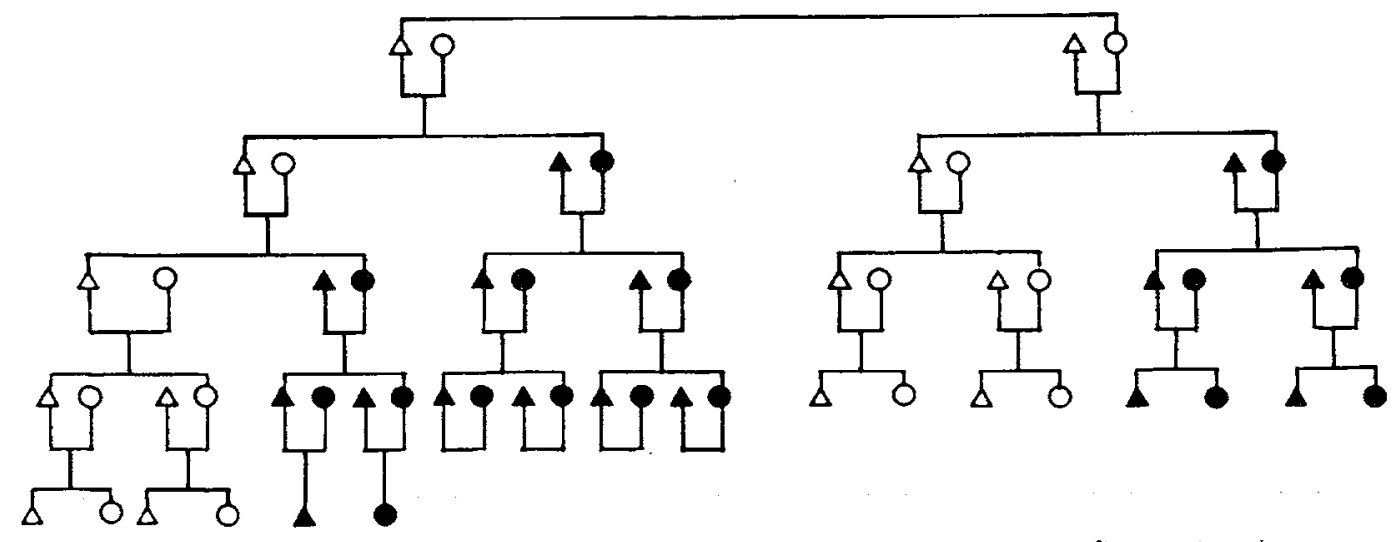

$\Delta O$ first network

$\Delta$ - second network

Diagram 2 : Lateral filiation 
ABORIGINAL HISTORY 1987 11:2

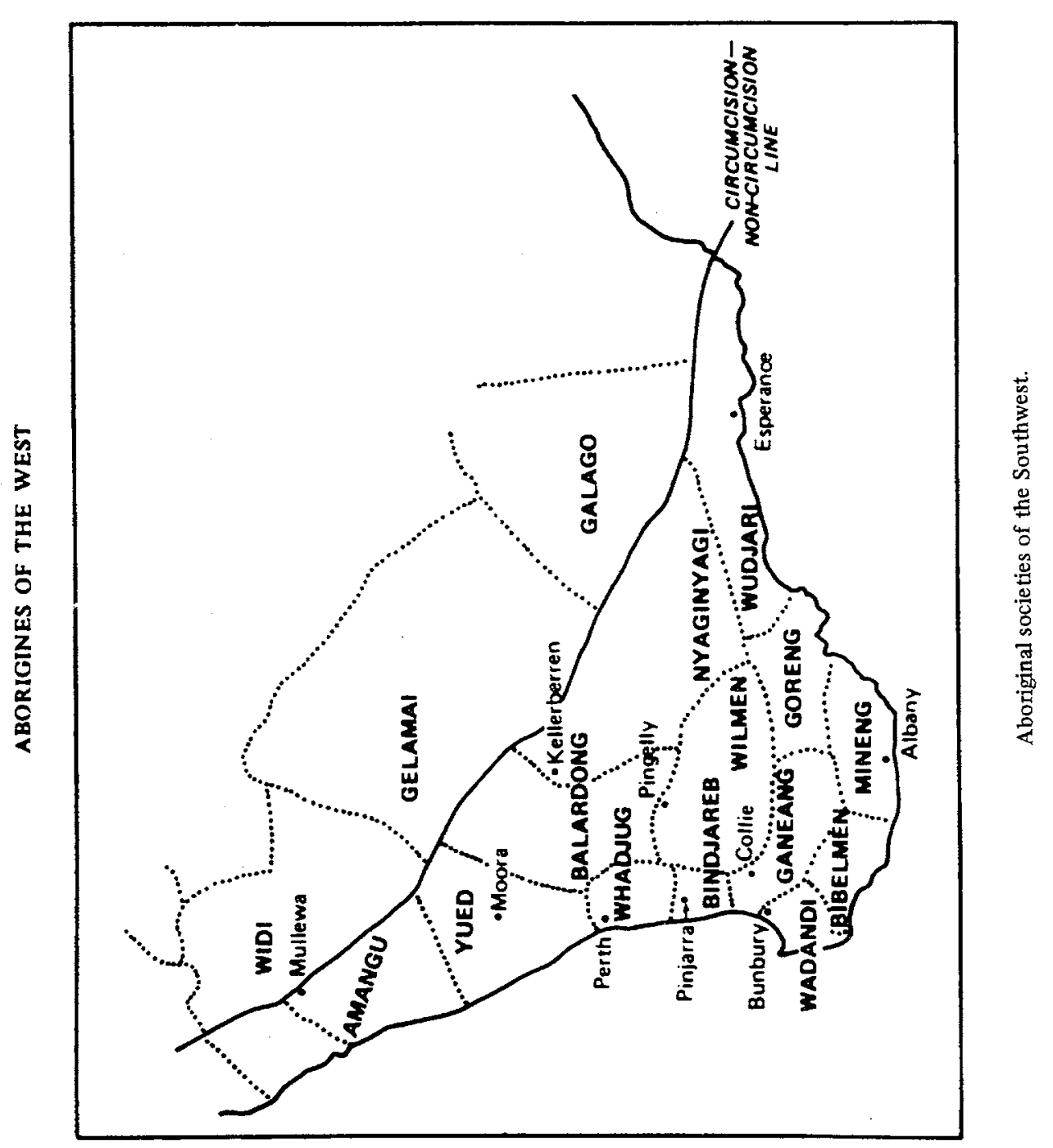


case, in that there were apparently many other kin with whom the senior members shared rearing-up relationships.

In this kin network income was derived primarily from the earnings of those members who were employed. As a group, they were noticeably better off than other larger kin networks which numbered 150 or more individuals.

One such network was part of the McNish all-one-family group. With 161 individuals, it was the largest kin network known to me. The McNish all-one-family numbers over three hundred individuals and so both its constituent networks of kin are quite large. The adult members of both networks claim to know one another well.

This is in marked contrast to the smaller, better-off group who acknowledged all their kin but claimed that they did not know them very well, and that they 'never have much to do with them'. In the large kin networks, like the McNish's, income is derived primarily from pensions and other social security and welfare payments. At this point, it is worth quoting Collman's reading of Sahlins:

Sahlins . . . suggests that kinship systems which encourage an extensive identification of collateral kin with lineal relatives command greater surpluses and generate more intensive economic systems than systems that emphasize lineal descent. The key factor is the relative isolation of the immediate family or domestic group from the rest of the community. The more isolated the domestic group, the lower is the total societal production and the smaller the economic surplus beyond basic needs. Sahlins' point is that lineal descent systems tend to isolate the basic domestic group more than systems that extend domestic ties along collateral lines. Although he does not say so, his analysis suggests that a domestic groups that wanted to justify isolating itself from the wider community might adopt a kin ideology that stressed lineal filiation or descent. ${ }^{10}$

In the Nyungar system, which emphasises laterality rather than lineality in group recruitment, people may in certain circumstances push this option to its extreme in order to increase the size of the group, as the McNishes seem to have done. Economic advantage may be gained by this means, because more incomes are made available to the group and more options are therefore present for individuals to seek aid in time of hardship. However, a group which was relatively well-off would gain no advantage by being recruited into a larger one. Their economic well-being would be eroded by the demands of their less well-off kin. The well-off group may therefore seek to protect its standard of living by limiting its size. They may do this within the Nyungar system by not taking full advantage of the option for extensive identification of matrilateral kin with lineal relatives.

I did not systematically collect data on incomes and consumption habits within these smaller, apparently more affluent groups. However should such a study be undertaken it might be expected to show a positive relationship between a group's size and its income, taking into account other historical factors such as have been discussed and which will affect the size and composition of a group. These features of size and composition thus provide clear indications which mark a group that, for example, has lived in poverty for a considerable period of time.

The McNish family is one such group. On first observation there appeared to be an un-

10 Collman 1979:392. 
usually small proportion of adult men within the group. Yet when a genealogy was compiled it showed a more even distribution of age and sex; as time went on and field observation continued, these men began to appear on the scene. Some arrived singly, down from the north where they had contract jobs on road works projects or mining ventures. They stayed for their holidays and would then board the bus back north. Others arrived in groups of three or more by car. They stayed for varying periods of time until they became too much of a nuisance through excessive drunkenness and 'noisy' behaviour and then were urged on.

To all appearances, these were the marginal or peripheral men of Black American ghetto studies. ${ }^{11}$ Questioning revealed that this kin network moved north two generations ago in response to a number of factors, among them the availability of work on the pastoral stations. Employment dropped in the pastoral industry around the early 1960s and Aboriginal men and women could no longer find work in the north. The women could get additional support from the government on account of their children, but the men could not. The family seems to have depended for its income primarily on pensions and other social security and welfare payments for the last twenty years. As a consequence of the economic importance of women, other developments have occurred.

The matri-centred tendency has become absolute. In this kin group women never leave their matri-kin and will leave their husbands more readily than women from other families. Formerly, in the reckoning of descent they emphasised links established through kinship with the father of the third ascending generation. But now they emphasise links through his wife. Formerly the preferred choice of residence on marriage, that men go the woman's way, was not necessarily the way all men chose to behave. Most men in fact did follow their wives, but some of them brought wives 'home', that is to their mother's homes. As well, most of the men of two generations ago in the McNish group successfully established marriages and fathered children.

This is in contrast to the present adult generation of the kin network. The men bring their wives home, but the women do not stay, preferring to live among their own kin. The greater proportion of these men have failed to establish successful marriages, and few have fathered children, at least that they are aware of.

In the McNish family, there is evidence that this situation may change by the time the present generation of adolescents becomes adults. Their older brothers and younger uncles generally look for station work, road work and other forms of unskilled, rural oriented labour when they are in search of work. The young boys talk about apprenticeships, truck driving and working on building sites. Few yearn for work on a shearing team or a cattle station. They admire big machines and the men who operate them As well, their contempt for drunken people is immense. If they can find steady, well-paid work in occupations that conform to their present ideals and aspirations, then the kin network may change again in response to the increased respect and authority the men will gain as a result of becoming steady sources of income to their relations. Ideologies of marriage and affiliation will swing away from the extreme of the matri-centred continuum.

Beckett $^{12}$ and Collmann ${ }^{13}$ both found among the Aboriginal groups they studied that

11 See for example the work of Charles Valentine (1968) and Elliot Liebow (1967).

12 Beckett 1958.

13 Collman 1979. 
the status of men relative to women was dependent on whether or not a man had steady employment and whether or not he lived with his wife and children on a regular basis. Beckett's and Collman's evidence of men's status included women's loyal ty to the ties of marriage, men's authority within the household and the preference in the affiliation of children with their matri-kin versus their patri-kin. There is evidence of this trend among the Nyungars, both in the present and historically.

Knowledge of the history of a Nyungar all-one-family is central to an understanding of its constituent kin networks. With this in mind, let us take a closer look at the history of the McNish family.

The McNish all-one-family has a long and well-established history of association with the northern wheatbelt region of Western Australia, as is shown in the mission records at New Norcia and those of the Moore River Native Settlement. The McNishes are remembered by the older people from other Nyungar kin groups as a large and cohesive group. As the older women of the family tell it, the core of the family in the Moore River days (as they term their sojourn there) was the strength of the relationship between three brothers, Charles, David and Ronald. In their young days it is said that they were very wild, but they grew up to be men of steady purpose. Charles retained a reputation for a fearsome temper that could be roused easily. David and Ronald married women from the South, but Charles married a woman named Elizabeth Jones from the Kimberley region.

Elizabeth Jones was the daughter of a part-Aboriginal woman and a white man. Her father was an adventurer, and one of his ventures was a cattle station in the Kimberleys. Elizabeth was born in town and grew up on the cattle station. She and her brother and sisters were brought up as their father's children, in the station house, unlike the Aboriginal children of many white pastoralists of that era. The majority of these men left their children by Aboriginal women to be brought up by their Aboriginal relations. When she was nine years old, Elizabeth's father sent her away to a mission in the Kimberley region. He sold his pastoral lease the following year.

The new lessee had not arrived to take over the station by the next year when Elizabeth's father sent his remaining Aboriginal children to join Elizabeth at the mission. When the mission priest came for the children, their father wept and told them that the station would 'always be your home'. As he had already given up the station, he obviously knew that his children could never return to their old life there, and so it is difficult to know why he said this. But he may have meant that they would be able to find camping grounds on the station. Perhaps he foresaw their future and that of their children as making their living by providing a pool of ready labour for whoever ran the station. His children, however, understood him to mean that the station was theirs and that they would live there again as the cocky's children when they left the mission.

Elizabeth's father never returned to the north-west and if he ever thought about his Aboriginal family again, it can't have been with any feeling deeper than fond regret. He died in Victoria. His Will described him as retired, unmarried, with no dependents. He left nothing to any of his Aboriginal family. Elizageth, aged eighty-two when I knew her, still believed that her father would never have left his family unprovided for and that it was all a dreadful mix-up.

Elizabeth ran away from the mission at the age of eighteen. She made her way back to town to find her mother. Two years later, she was sent by ship to Fremantle and then by train to the Moore River Native Settlement. There she met Charles McNish and, at the age of 
twenty-four, she married him.

The McNish family remained a united group while the three brothers all lived. But after Charles died, Elizabeth began to talk of going back to the Kimberley town. Her husband and children had been employed on stations, progressively working their way northward for many years. The Gascoyne River region was becoming well-known to them. Then, rural employment began to drop and the Aborigines were the first to be affected. With the old man dead, and no hope of employment in the area with which they were most familiar, the wheatbelt region, Elizabeth and her children went north. Over the years, they found sporadic employment on the stations in the Gascoyne region. Elizabeth went to work on a station in the Kimberleys with one of her daughters. When that job finished she and her daughter went to the Kimberley town.

Those of Elizabeth McNish's children who now lived in and around the Gascoyne region would occasionally see their relations who had remained in the wheatbelt. Elizabeth's elder daughters had all married boys from the south and they too retained their kin links within the south-west. Certain of the wheatbelt McNishes came north and affiliated with the northern McNish group. Children of the northern McNishes similarly went south to the wheatbelt and came to associate predominantly with that branch of the family. And although they continued to assert that they were 'all-one-family', it was evident that two separate networks of kin had formed.

For example, in 1975, one of the young men was involved in a road accident. He required medical attention that was available only in Perth. He was transferred from the district hospital at Carnarvon, accompanied by his mother. He would always need medical attention and his mother decided that he should remain in Perth. So she brought her dependent children down from the north and established residence in Perth. This move considerably reduced the distance between themselves and the wheatbelt McNishes, putting them within two or three hours travelling time of one another, whereas before it was an entire day's journey from one group to the other. Now the two sections of the Gascoyne McNish family are a full day's journey apart.

But despite their new proximity to one another, the family in Perth and the family members of the wheatbelt towns did not re-affiliate with one another. No regular visits were exchanged. The family now in Perth pursued their extant links with the family in the Gascoyne. These two sections of the network maintained the unity of their group though regular visits. Some people from the Gascoyne came to Perth to live with or near their aunt; some of their aunt's children returned to the Gascoyne to marry and to live. Neither section showed any signs of splitting away to form a new, independent network of kin.

Elizabeth McNish never went back to the wheatbelt region. At one point, twelve years went by before she visited her family in the south, though many of them had come to the Kimberley town to see her. She finally went to the Gascoyne on the occasion of the funeral of her eldest grandson. The next year, her late husband's sister Kitty McNish died at Moora.

Elizabeth had been close to her sister-in-law in the old days. They had helped rear-up one another's children and their children were still fond of one another, or so the evidence of their conversations suggested. As well, the dead woman had been as important a force behind the formation of her kin network as Elizabeth had been within her own. But Elizabeth did not go to her sister-in-law's funeral and neither did any of the family living in the Kimberley town. The family in the Gascoyne and at Perth all attended however, and were embarrassed to find Elizabeth not there and further embarrassed that she sent neither a card 
nor flowers to the children of the deceased. 'We never got word,' said Elizabeth. But she never did send a card.

Elizabeth's neglect in this regard is unusual and must be taken as being of signal importance. Nyungar people place high priority on the idea of respect for the dead;' showing respect for the dead is acknowledgement of one's historical relationship with the deceased person. This person need not have been kin. For example, it is proper to go to the funeral of a non-kin person who was a close and significant associate in a social situation which has long since ceased to exist, such as a mission or a settlement, or a station camp. 'He was a good old soul. We ought to go to his funeral.'

In failing to even acknowledge the death of her husband's sister, Elizabeth effectively denied her once close relationship with that woman, and by extension with the rest of her family-in-law. Symbolically, she devalued her affinal ties with that family.

Elizabeth's apparent urge to return to the Kimberley town is the result of her childhood experience. When she was taken from her family and placed in the mission, she was deprived of what she saw as her birthright, that is, her station life. She was also deprived of her mother. For the next nine years, until she was eighteen, it was her consuming desire to get home and find her mother. It was interesting that in the course of telling her story, Elizabeth never spoke of a similar desire to find her father. Her identity throughout her life seems to have been based on her mother's heritage of place. She was an Aboriginal woman of the Kimberley town and that was all Elizabeth, in the end, desired to be. Next to this desire to live in her mother's country, Elizabeth's established identity as a woman of a well-known Aboriginal wheatbelt family seems to have counted for little. She never denied her children's cultural heritage as Nyungars, but it became apparent that she had ceased to claim it for herself.

According to the influences of history and events occurring in the lives of individuals, kin networks arise out of cognatic descent groups. Kin networks serve to join groups of kin located in a set of towns into a single social unit. This social unit reflects the history of the individuals who constitute that unit through features of social organisation and group composition and through the identification of individuals with places which they regard as their 'true' or 'real' homes. This relationship between kin group membership and place forms the basis of social and personal identity among Nyungar people.

\section{BIBLIOGRAPHY}

Australia. Department of Territories. One people. Prepared under the authority of the Minister for Territories with the co-operation of the Ministers responsible for Aboriginal Welfare in the Australian States for use by National Aboriginal Observance Day Committee, 14 July, 1961. Canberra, 1961.

Bates, Daisy. The native tribes of Western Australia. I.M. White ed. Canberra, 1985.

Beckett, Jeremy. A study of mixed-blood Aboriginal minority in the pastoral west of New South Wales. M.A. thesis, Australian National University, 1958.

Berndt, Ronald M. 'The Aborigines of the south-west', in Ronald M. and Catherine H. Berndt eds, Aborigines of the west: their past and their present, revised edition pp.81-89. Perth, 1979/1980.

Birdsall, Christina L. All one family: family and social identity among urban Aborigines in Western Australia. Ph.D. thesis, University of Western Australia, 1988.

Biskup, Peter. Not slaves not citizens: the Aboriginal problem in Western Australia 1898-1954. Brisbane, 1973. 
Collman, Jeff. 'Women, children, and the significance of the domestic group to urban Aborigines in central Australia', Ethnology 18(4) 1979:379-97.

Douglas, Wilfrid H. The Aboriginal languages of the south-west of Australia, 2nd edition. Canberra, 1976.

Haebich, Anna. 'On the inside: Moore River Native Settlement in the 1930s', in B. Gammage and A. Markus eds, All that dirt: Aborigines 1938, pp.44-66. Canberra, 1982.

'A bunch of cast-offs': Aborigines of the southwest of Western Australia. Ph.D. thesis, Murdoch University, Western Australia, 1985.

Handbook of Western Australia, vol. 5, 1905.

Howard, Michael C. 'Migration and inequality: the socio-cultural significance of Australian Aboriginal internment in southwestern "Native Settlements" ', Anthropological Forum 4 (3-4) 1980:297-307. Aboriginal politics in southwestern Australia. Nedlands, Western Australia, 1981.

Liebow, Elliot. Tally's Corner. London, 1967.

Tindale, Norman B. 'Distribution of Australian Aboriginal tribes: a field survey', Transactions of the Royal Society of South Australia 64 (1) 1940:140-232.

Valentine, Charles. Culture and poverty. Chicago, 1968.

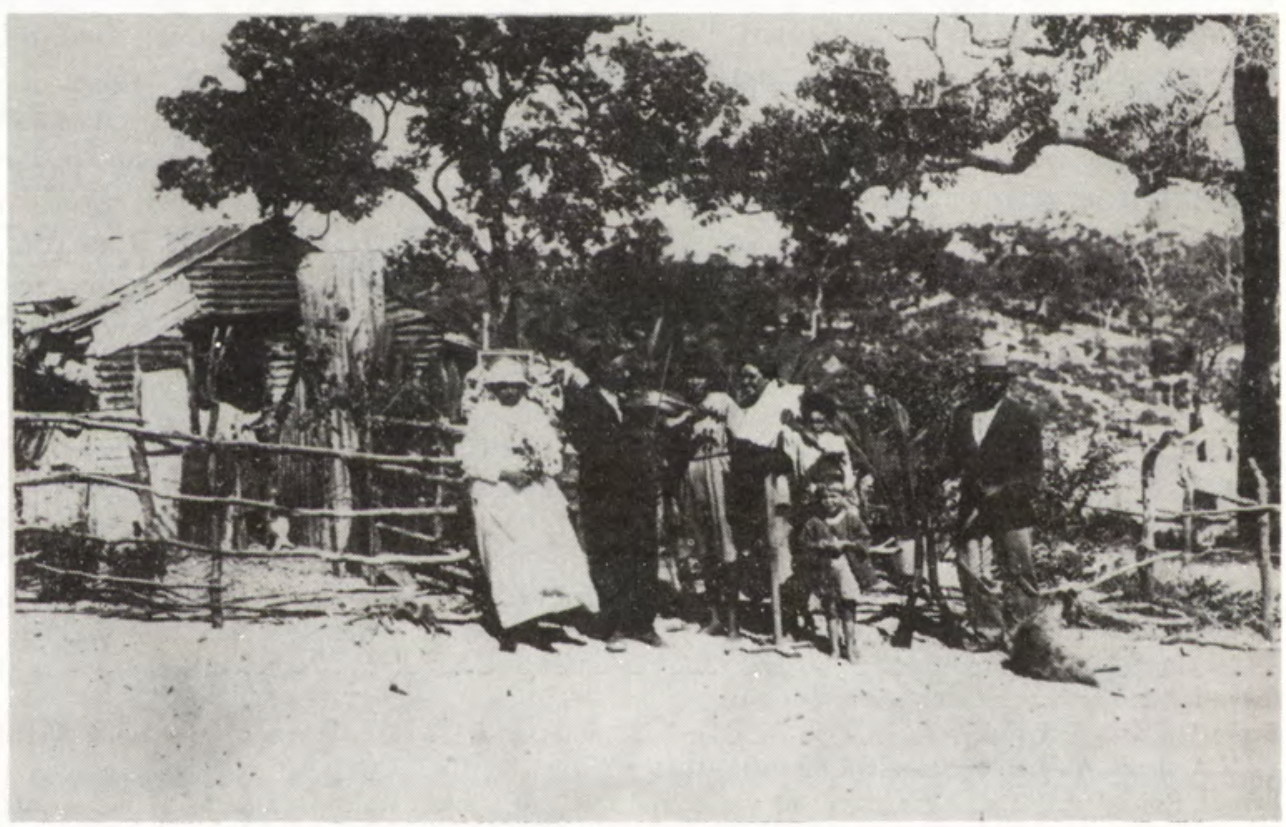

Wedding group, Moore River, Western Australia, 1930.

Photo: Colbung collection, Australian Institute of Aboriginal Studies. 